\title{
Penerapan Permainan Origami untuk Meningkatkan Kreativitas Siswa di MIM Pepe, Klaten
}

\author{
Puspita Indra Wardhani ${ }^{1}$, Agusta Aulia Urrochman ${ }^{2}$, Anisa Nur Alimah ${ }^{3}$, Ida Fatmawati ${ }^{4}$, Ika Rifn- \\ gatin $^{5}$, Nur Baiti Sukma Dewi ${ }^{6}$, Rizki Hendrawan Wibisono ${ }^{7}$, Rossy Andriani ${ }^{8}$, Sendy Pratiwi ${ }^{9}$ \\ ${ }_{1,2,3,4,5,6,7,8,9}$ Fakultas Keguruan dan Ilmu Pendidikan, Universitas Muhamamdiyah Surakarta, Indone- \\ sia
}

\section{INFORMASI ARTIKEL}

\section{Histori Artikel:}

Submit: 27 April 2020

Revisi: 2 Mei 2020

Diterima: 4 Mei 2020

Publikasi: 6 Mei 2020

Periode Terbit: Desember 2019

\section{Kata Kunci:}

kemampuan,

kreativitas,

percaya diri

\section{Correspondent Author:}

Agusta Aulia Urrochman

Fakultas Keguruan dan Ilmu Pendidikan

Universitas Muhammadiyah Surakarta,

Indonesia

Email:

a610160005@student.ums.ac.id

\begin{abstract}
ABSTRAK
Kreativitas anak tidak didapatkan sejak peserta didik lahir, namun kreativitas anak dapat dikembangkan melalui sebuah kegiatan atau pelatihan yang terbimbing. Meningkatkan kreativitas pada siswa sebagai suatu upaya untuk mengembangkan keterampilan dan memacu rasa ingin tahu anak. Peran Pendidikan formal di sekolah cukup besar dalam hal ini, dimana sekolah menjadi sarana pengembangan kreativitas anak yang tentunya tidak lepas dari peran pendidik. Oleh karena itu, pendidik berperan penting dalam pengembangan keterampilan siswa MIM PEPE dalam berkreativitas, didukung dan dikelola dengan baik. Hal ini dapat dicapai jika siswa dan guru dapat berkolaborasi secara baik untuk mencapai suatu tujuan yang dirancang bersama. Data menunjukkan bahwa banyak siswa MIM PEPE yang belum semua dapat mengembangkan kreativitas dan skillnya. Faktor utama yang mendorong keberanian siswa untuk meningkatkan kreativitasnya adalah bimbingan guru dan fasilitas yang memadai untuk pengembangan siswa. Rasa percaya diri pada siswa dalam meningkatkan skill personalnya merupakan tanggung jawab siswa itu sendiri dan tentunya didampingi oleh peran guru. Tujuan dari pengabdian ini adalah untuk meningkatkan kepercayaan diri siswa dalam mengembangkan kreativitasnya. Subjek dalam pengabdian yaitu siswa kelas 1, 2 dan 3. Adapun objek pengabdiannya adalah kemampuan kreativitas peserta didik. Hasil pengabdian ini menunjukkan bahwa kreativitas anak dapat berkembang disertai dengan peran guru.
\end{abstract}

\section{Pendahuluan}

Keterampilan merupakan kreativitas seorang manusia yang bersifat personal. Kreativitas personal individu dapat dikatakan skill dari lahir dan juga dapat diasah serta dilatih. Setiap diri manusia memiliki tingkat kreativitas yang berbeda. Rogers (1962) dalam bukunya menjelaskan bahwa kreativitas adalah kecenderungan untuk mengaktualisasikan diri, mewujudkan potensi dan berkembang, menjadi matang dan kecenderungan untuk mengekspresikan dan mengaktifkan semua kemampuan organisme. Sternberg (1988) memberikan definisi "three facets of creativity" tiga atribut dalam psikologis yaitu intelegensi, gaya kognitif, dan kepribadian/ motivasi.

Kreativitas digunakan untuk memproses suatu produk yang orisinil. Hal ini adalah proses seseorang memberikan opini dan kreasi namun proses perkembangannya berbeda setiap indi- 
doi: 10.23917/bkkndik.v1i2.10773

vidu (Smith, 1996; Twigg \& Yates, 2017). Pemberian kreativitas pada kurikulum sekolah merupakan suatu hal yang harus dilakukan. Menciptakan lingkungan belajar untuk perkembangan kreativitas anak dapat membantu anak belajar untuk tidak takut membuat kesalahan dan berani mengambil risiko (Smith, 1996).

Kreativitas dalam perkembangannya tidak hanya digunakan dalam kepentingan personal, namun juga dapat digunakan dalam kelompok luas. Perkembangan zaman pada era ini menuntut seorang individu untuk pintar mengembangkan kreativitasnya agar tidak tertinggal oleh kemajuan teknologi yang semakin pesat dan canggih. Bagi seorang siswa, menguasai lebih dari satu keterampilan, terutama kreativitas itu sangat penting. Keterampilan melukis kaligrafi merupakan salah satu contoh kreativitas yang sangat pesat perkembangannya bahkan digunakan untuk mengurangi kecanduan game online pada anak (Saputro, 2018).

Perkembangan kreativitas anak dapat dilakukan melalui berbagai aktivitas dalam keseharian melalui seni dan musik. Kreativitas siswa dapat dioptimalkan menggunakan media pembelajaran, salah satunya menggunakan media kertas origami yang mampu meningkatkan kreativatisnya. Origami adalah salah satu aktivitas seni yang bermanfaat untuk anak-anak salah satunya untuk mengasah kreativitas dan imajinasi anak (Puspitaningrum dkk., 2019; Setiawati, 2019).

Secara umum, kertas origami lebih menarik dibandingkan dengan kertas biasa, karena kertas origami memiliki desain dan warna yang beragam sehingga lebih menarik untuk digunakan sebagai media pembelajaran. Kegiatan pembelajaan untuk mengembangkan kreativitas anak menggunakan kertas origami termasuk dalam kemampuan seni dan fisik.

Origami adalah suatu teknik berkarya seni atau kerajinan tangan yang umumnya dibuat dari bahan kertas dengan tujuan untuk menghasilkan aneka bentuk mainan, hiasan, benda fungsional, alat peraga dan kreasi lainnya (Sumanto:2005). Karmachela (2008), berpendapat seni melipat kertas ini merupakan seni yang sangat cocok bagi anak, karena origami melatih keterampilan tangan anak. Selain itu juga kerapian dalam berkreasi, anak akan terbiasa untuk menciptakan hal baru atau inovasi.

Melipat kertas adalah aktivitas seni yang mudah dibuat dan menyenangkan. Diantara perannya adalah sebagai aktivitas untuk mengisi waktu luang dan media pengajaran dan komunikasi dengan anak karena bisa dilakukan secara bersama-sama. Selain itu, melipat kertas juga sangat fungsional untuk anak dan aktivitas ini memiliki fungsi melatih motorik halus dalam masa perkembangannya (Maya, 2010).

Origami dalam beberapa kurikulum pendidikan digunakan untuk meningkatkan kemampuan anak dalam matematikan terutama geometri (Boakes, 2009; Liu, 2019; Gur \& Demir, 2017). Origami juga digunakan untuk meningkatkan motorik pada anak disabilitas (Pradipta \& Dewantoro, 2019). Origami dalam bidang kesehaan digunakan untuk sebagai terapi untuk mengurangi tingkat kegelisahan pada anak-anak yang sedang menjalani perawatan di rumah sakit (Pribadi dkk., 2018).

\section{Metode Pelaksanaan}

Pengabdian ini dilaksanakan di MIM Pepe Ngawen pada saat pelaksanaan KKNDik, yaitu pada tanggal 21 Januari sampai dengan 3 Maret 2020. Subjek pengabdian ini adalah pe- 
serta didik kelas 1, 2 dan 3 sedangkan objek pengabdian ini adalah kemampuan kreativitas siswa dalam menggunakan media origami.

Penggunaan media origami ini diharapkan dapat meningkatkan kreativitas siswa dan dapat menghasilkan keterampilan yang indah guna memacu siswa agar terus mengasah kreativitasnya. Kegiatan ini sejatinya bertujuan untuk memotivasi kepercayaan diri siswa untuk meningkatkan kreativitasnya. Alat dan bahan yang digunakan dalam kegiatan ini pun hanya sederhana, kertas origami berbagai ukuran, gunting, tali dan double tape. Pada kegiatan kali ini, mahasiswa KKNDik FKIP UMS membimbing siswa dalam membuat keterampilan dari kertas origami dengan memberikan kebebasan untuk peserta didik berkreativitas. Mahasiswa mendemonstrasikan cara membuat suatu karya dengan menggunakan kertas origami. Adapun uraian kegiatannya sebagai berikut.

1. Persiapan bahan dan alat

Persiapan bahan, yaitu kertas origami dengan berbagai ukuran, tali dan double tape. Adapun alatnya, yaitu gunting. Kegiatan ini dilaksanakan di tiga kelas, yaitu kelas 1, 2 dan 3 dengan jangka waktu yang teratur.

2. Kegiatan demonstrasi

Demonstrasi dilakukan dimasing-masing kelas dengan melibatkan 3/4 mahasiswa KKNDik FKIP UMS dengan membuat keterampilan/ karya yang sama tetapi tetap membebaskan untuk berkreativitas.

Sebenarnya tujuan lain dari kegiatan ini selain untuk memotivasi kepercayaan diri siswa juga untuk meningkatkan kreativitas. Kreativitas tersebut salah satunya menghias kelas dengan hasil kerja tangan, dapat membuat peserta didik bangga dengan hasil kerja peserta didik dan pembelajaran dapat berlangsung secara nyaman karena kelas menarik dan tidak membosankan.

Peneliti ingin melihat bagaimana antusias siswa dalam pembuatan karya dengan kertas origami dan bagaimana kreativitas peserta didik terhadap karya yang sudah peserta didik buat. Peneliti juga melakukan wawancara terhadap guru di MIM PEPE untuk mengetahui tanggapan guru terhadap penerapan origami untuk memotivasi kepercayaan diri siswa guna meningkatkan kreativitas.

\section{Hasil Pelaksanaan dan Pembahasan}

Memotivasi kepercayaan diri peserta didik kelas 1, 2 dan 3 dengan kreativitasnya dengan menggunakan kertas origami dapat dikatakan cukup berhasil. Hasil yang didapat berdasarkan kegiatan demonstrasi yang sudah dilaksanakan di MIM PEPE, sebenarnya memotivasi kepercayaan diri untuk meningkatkan kreativitas tidak hanya diterapkan di kelas 1, 2 dan 3 tetapi juga di kelas 4, 5 dan 6. Akan tetapi, karena terlalu banyaknya kelas yang harus di tangani dan mengingat singkatnya waktu yang diberikan untuk melaksanakan KKNDik memutuskan hanya melakukan kegiatan ini di kelas 1, 2 dan 3. Hal ini didasarkan pada kebutuhan edukasi dan motivasi untuk meningkatkan kreativitas siswa tersebut.

Berdasarkan kegiatan yang sudah dilaksanakan menunjukan bahwa kegiatan dilakukan selama 3 kali pada minggu ke 3, 4 dan 5 di kelas 1, 2 dan 3 setiap hari Selasa, Rabu, dan Penelitis. Hasil yang didapat di kelas 1, 2 dan 3 hampir memiliki persamaan dan perbedaan. Berikut ini langkah-langkahnya: 


\section{Pemberian Materi}

Pemberian materi dilakukan pada minggu ke 3 saat melaksanakan KKNDik dengan materi yang telah ditentukan, yaitu pengembangan kreativitas menggunakan media origami. Materi ini mengharapkan peran aktif siswa dalam berimajinasi dan berkreasi. Dengan cara mengembangkan bentuk dan ragam hasil yang dapat dihasilkan dari sebuah kertas origami yang hanya berbentuk segiempat. Pada penggunaan kertas origami menerangkan suatu kesenian melipat kertas yang dipercayai bermula sejak kertas diperkenalkan pada abad tahun 105 Masehi oleh Ts'ai Lun. Disini peserta didik mulai dilatih untuk berimajinasi dan berkreativitas dengan membuat dasar-dasar origami seperti perahu atau yang lainnya. Disini peneliti memilih dua peserta didik untuk mencoba memperagakan atas apa yang sudah peserta didik kreasikan dengan selembar kertas origami yang telah dibagikan. Kegiatan ini sama halnya dilakukan di kelas 1, 2 dan 3. Dua peserta didik yang maju untuk mempraktikkan hasil kreativitas peserta didik tersebut dipilih langsung oleh peneliti sebagai perwakilan karna di masingmasing kelas ketika peneliti meminta dua orang untuk maju tidak ada yang maju dan akhirnya peneliti yang memilih. Dari sini dapat disimpulkan bahwa tingkat percaya diri peserta didik masih kurang dan perlu adanya motivasi bukan dalam hal berbicara tetapi juga untuk segala hal yang berkaitan dengan pengembangan skill.

\section{Bimbingan}

Pada pertemuan kedua ini satu jam pelajaran peneliti gunakan untuk membimbing peserta didik dalam membuat serta mengkreasikan sebuah kertas segiempat agar bisa menjadi sebuah bentuk yang beragam. Peneliti meminta peserta didik untuk memilih salah satu dan dikerjakan secara individual. Kegiatan kali ini peserta didik diminta untuk mengamati benda sekitar yang sekiranya mudah untuk dijadikan atau dikembangkan dari kertas origami. Kegiatan selanjutnya (pertemuan ketiga) peserta didik diminta untuk mempraktikkan dan membawa kertas origami dan peralatan yang dibutuhkan sesuai dengan benda atau tema yang peserta didik pilih. Sama seperti kegiatan sebelumnya, kegiatan ini juga dilakukan di tiga kelas yaitu kelas 1, 2 dan 3 akan tetapi, pada pertemuan kedua ini peneliti menemukan perbedaan antara dua kelas ini. Kelas 3 cenderung lebih aktif dan percaya diri dalam menanyakan hal-hal yang tidak diketahui kepada peneliti. Siswa kelas 3 juga lebih berinovasi dalam dengan membuat bentuk-bentuk hewan dan peserta didik juga mulai berlatih mengkreasikan kertas yang peserta didik miliki menjadi hewan sekitar seperti burung dan peneliti diminta mengkoreksi benar atau tidak bentuk yang telah dibuat. Disisi lain, peserta didik kelas 2 sudah mulai percaya diri namun masih memerlukan pendampingan secara langsung dengan melakukan pendekatan. Peneliti harus aktif bertanya tentang kesulitan yang peserta didik alami. Kegiatan disetiap pertemuan diakhiri dengan pemberian motivasi kepada peserta didik bahwa menumbuhkan rasa percaya diri itu sangat penting, terutama dalam kemampuan mengembangkan kreativitas dan kemampuan yang peserta didik miliki. "Tetap berusaha, jangan takut salah, jangan malu. Malulah ketika kamu tidak belajar sama sekali padahal kalian adalah seorang pelajar." Kata itulah yang sering peneliti katakan ketika dikelas. 


\section{Praktik dan menghias kelas}

Kegiatan kali ini peserta didik diminta mempraktikkan hasil pekerjaan yang telah dikerjakan pada pertemuan sebelumnya secara individu. Disini peneliti dapat mengamati satu persatu peserta didik kelas 1, 2 dan 3 terhadap tingkat percaya diri dan kemampuan berkreasi. Hasil pengamatan peneliti, peserta didik sudah percaya diri dalam membuat kreativitas origami, namun masih dijumpai sejumlah peserta didik yang masil malu-malu dalam mengembangkan ide.

Berdasarkan hasil pengamatan dan praktik di kelas, dapat disimpulkan bahwa peserta didik sudah mampu menguasai diri untuk mengembangkan kemampuan dan membangun rasa percaya diri dalam menyampaikan ide. $\mathrm{Pa}$ da pertemuan ini peneliti memfasilitasi bahan tambahan untuk mengabadikan hasil kreasi peserta didik yang dijadikan sebagai hiasan kelas peserta didik masing-masing yaitu kelas 1, 2 dan 3.

Hasil dari kegiatan praktik yang telah dilakukan, beragam bentuk kertas origami sudah didapat dan dengan kreativitas peserta didik membuat hasil yang didapat menjadi semakin indah. Hasil kerja peserta didik meliputi bentuk hati, burung, kupu-kupu, ikan dan bunga tulip. Ini adalah hasil yang cukup memuaskan bagi peneliti, peserta didik mampu membuat dan menambahkan kreasi sehingga menghasilkan bentuk yang lebih indah. Salah satu kreativitas siswa yang nyata yang membuat peneliti bangga adalah ada salah satu siswa yang membuat kupu-kupu dan dengan idenya dia menambahkan anggota tubuh kupu yang lainnya dengan kertas yang sudah dia gambar sesuai dengan bentuk anggota tubuhnya digunting lalu ditempel serta memberikan gambar/ motif pada kupu-kupu sehingga terlihat lebih indah.

Terlepas dari hal itu, tahap akhir dari kegiatan ini adalah hasil kerja peserta didik yang akan dipergunakan untuk memperindah kelas peserta didik yang diharapkan dapat membuat kelas lebih menarik dan tidak membosankan sehingga semangat peserta didik dalam belajar tinggi. Adapun hasil kerja peserta didik yang dipergunakan untuk menghias kelas meliputi:

a. Bentuk hati, burung dan bunga yang disusun menggunakan tali untuk menghias jendela kelas (digantung).

b. Bentuk kupu-kupu yang ditempel di dinding kelas untuk memperindah kelas agar menimbulkan kesan yang ceria karena beragam warnanya dan cerah tentunya serta untuk mengisi space yang kosong agar terlihat menarik.

c. Bentuk bunga tulip yang diletakkan di vas bunga, batang bunga tulip berasal dari lidi dan sedotan untuk memperindah meja guru di kelas.

d. Bentuk ikan ditempel juga di dinding kelas untuk memperindah kelas serta di tempel di mading agar lebih menarik.

Tiga pertemuan yang telah dilakukan dirasa memberikan manfaat yang begitu besar kepada peserta didik dalam upaya memotivasi rasa percaya diri peserta didik dalam meningkatkan dan mengembangkan keterampilan. Rasa percaya diri bisa tumbuh secara perlahan dengan diberi motivasi dan kegiatan-kegiatan yang dapat menumbuhkan rasa percaya diri. Oleh karena itu kegiatan ini diharapkan dapat menjadi salah satu cara atau jalan untuk menumbuhkan rasa percaya diri peserta didik yang 
doi: 10.23917/bkkndik.v1i2.10773

berkaitan dengan peningkatan kemampuan kreasi peserta didik.

\section{Wawancara dengan Guru dan Siswa}

Peneliti melakukan wawancara terhadap salah satu wali kelas di MIM PEPE dan beberapa siswa dari kelas 1, 2 dan 3. Hasil wawancara kepada salah satu wali kelas yaitu rasa percaya diri para peserta didik di MIM PEPE memang harus lebih ditingkatkan lagi melalui pendekatan ataupun memotivasi para siswa secara langsung ketika di kelas maupun di luar kelas. Rasa percaya diri pada diri siswa erat kaitannya dengan capaian akademik peserta didik. Siswa yang tidak memiliki rasa percaya diri, akan kesulitan dalam berkembang. Ide-ide yang besar yang peserta didik miliki tidak mungkin dapat tersalurkan jika peserta didik tidak mempunyai kepercayaan diri. Kemampuan kreativitas pada siswa masih perlu ditingkatkan lagi agar kemampuan peserta didik dalam berkreasi semakin berkembang. Pendampingan dan pemberian motivasi melalui berbagai kegiatan untuk meningkatkan dan mengembangkan kreativitas peserta didik diharapkan juga dapat meningkatkan kepercayaan diri peserta didik.

Hasil wawancara terhadap enam peserta didik dari kelas 1, 2 dan 3 yaitu peserta didik sudah cukup merasa percaya diri ketika harus mengembangkan ide-ide baru peserta didik di muka umum, namun hal lain yang membuat peserta didik merasa tidak percaya diri adalah ketika peserta didik harus berbicara dan mendeskripsikan apa hasil temuan peserta didik serta beranggapan penemuan kreativitas baru tidak lebih penting dari mata pelajaran seperti matematika, bahasa inggris dan mata pelajaran yang lainnya.

\section{Peningkatan Kreativitas}

Rhodes (1961) membagi kreativitas kedalam empat pendekatan (4P) yaitu: Pl yaitu kreativitas adalah sesuatu ungkapan seseorang untuk menuangkan ide kreatifnya untuk menghasilkan sesuatu, P2 yaitu pendorong atau pengaruh orang tua dan lingkungan untuk mendapatkan bakat kreatif anak, P3 yaitu proses merupakan rangsangan anak untuk mengembangkan idekreatif dengan melakukan sebuah kegiatan yang dilengkapi dengan sarana dan prasarana yang baik, $\mathrm{P} 4$ yaitu produk, seseorang yang dapat menciptakan sesuatu dengan melibatkan dirinya.

Hasil kegiatan selama tahap pemberian materi hingga demonstrasi hasil karya di depan kelas terlihat adanya perubahan perilaku pada peserta didik. Berdasarkan pendekatan oleh Rhodes (1961) proses pembuatan origami di MIM Pepe menghasilkan luaran yaitu peserta didik mampu membuat kreasi bentuk-bentuk origami berdasarkan imajinasi sendiri (Narimo, et al, 2018). Peserta didik mendapat dukungan dari sekolah baik guru maupun fasilitas sekolah dalam mengembangkan kreativitasnya, kedepan kegiatan kreatif akan digunakan dalam proses pembelajaran di kelas. Peserta didik juga mengalami peningkatan rasa percaya diri dengan berani tampil di muka umum dalam mendemonstrasikan hasil kreativitasnya. Berdasarkan hasil pengamatan dari guru dan peneliti terhadap aspek kognitif peserta didik, menunjukkan adanya peningkatan rasa percaya diri dalam mengikuti kegiatan pembelajaran di kelas.

\section{Simpulan}

Penerapan strategi memotivasi kepercayaan diri melalui kreasi origami untuk peserta didik, sangat efektif untuk meningkatkan 
rasa percaya diri dan kemampuan mengembangkan kreativitas peserta didik. Guru sebagai kunci pokok keberhasilan siswa dalam belajar harus mempunyai banyak ide dalam menerapkan strategi pembelajaran yang cocok untuk disampaikan di kelas. Guru yang bisa memenuhi keinginan dan kebutuhan siswa maka akan membuat siswa termotivasi dalam belajar dan dapat meningkatkan hasil belajar peserta didik. Motivasi melalui kegiatan origami mampu meningkatkan rasa percaya diri dan mengembangkan kreativitas peserta didik kelas 1, 2 dan 3 di MIM PEPE. Pendampingan kegiatan yang bersifat kreasi sangan efektif dalam meningkat minat belajar peserta didik.

\section{Daftar Pustaka}

Boakes, N. J. (2009). Origami Instruction in The Middle School Mathematics Classroom: Its Impact on Spatial Visualization and Gemetry Kwnoledge of Students. RMLE Online. 32 (7). 1-12.

Gur, H \& Demir, M. K. (2017). Geometry Teaching via Origami: The Views of Secondary Mathematics Teacher Trainees. Journa; of Education and Practice. 8 (15). 65-71.

Karmachela, H. (2008). Seni Origami.

Leoniya. (2013). Pengembangan Kreativitas Seni Mewarnai Melalui Terapi Menggambar Pada Anak Tk. Https://leoniya.wordpress.com/2013/11/ $09 / 233$.

Maya, H. (2010). Kreasi origami favorit. Jakarta: Kawan Pustaka.

Narimo, S., Maryadi, M., Fatoni, A., Anif, S., Sumardjoko, B., \& Adhantoro, M. S. (2018, November). Pancasila and Citizens Education (PKn) Learning Based on Local Culture in The Establishment of Student Characters. In Profunedu International Conference Proceeding (Vol. 1, pp. 255-260).
Pradipta, R. F \& Dewantoro, D. A. (2019). Origami and Fine Motoric Ability of Intellectual Disabiliy Students. International Journal of Innovation. 5(5). 531545.

Pribadi, T., Elsanti, D., \& Yulianto, A. (2018). Reduction of Anxiety in Children Facing Hospitalization by Play Therapy: Origa$\mathrm{mi}$ and Puzzle in Lampung-Indonesia. Malahayati International Journal of Nursing and Health Science. 1(1). 2935 .

Puspitaningrum, D. A., Fitriyah, C. Z., Nurdianasari, N., Finali, Z., \& Ningsih, Y. F. (2019). Educative Game Tools with Origami Media for Increasing Creativity of Class Children in Elementary School. International Journal of Scientific \& Technology Research. 8 (9). 1923-1925.

Rhodes, M. (1961). An Analysis of Creativity. Phi Delta Kappa International, 42(7). 305-310.

Rogers, M. E. (1962). Diffusion of Innovations. New York: Free Press of Glencoe.

Saputo, Dimas. (2018). Efektivitas Terapi Kalgrafi untuk Menurunkan Gangguan Adiksi Game Onlne Pokemon Gi pada Siswa SMP Islam Al-Kautsar Semarang. Skripsi. Universitas Islam Negeri Walisongo.

Setiawati, W. (2019). Increasing Creativity of Early Childhood Through Origami Playing Activities. Jurnal Empowerment. 8(1). 81-89.

Smith, M. K. (1996). Fostering creativity in the early childhood classroom. Early Childhood Education Journal, 24 (2), 77-82.

Sternberg, R. J. (1988). A three-facet model of creativity. In R. J. Sternberg (Ed.), The nature of creativity: Contemporary psychological perspectives (125-147). Cambridge University Press.

Sumanto. (2005). Pengembangan Kreativitas Seni Rupa Anak TK. Jakarta. Departemen Pendidikan Nasional. 
Yates, E \& Twigg, E. (2017). Developing creativity in early childhood studies stu- dents. Thinking Skills and Creativity, (23) 42-57. 